Cybernetics, Vinnytsia National Agrarian University (21008, Vinnytsia, 3 Soniachna St., e-mail zeloksanavlad@gmail.com).

POTAPOVA Nadin - Candidate of Economic Sciences, Associate Professor, Department of Computer Science and Economic Cybernetics of Vinnytsia National Agrarian University (21008, Vinnytsia, 3 Soniachna St., e-mail: potapova.nadin@gmail.com).

ВОЛОНТИР Людмила Алексеевна - кандидат технических наук, доцент, доцент кафедры компьютерных наук и економической кибернетики, Винницкий национальный аграрный університет $(21008$, г. Винница, ул. Солнечная, 3, еmail: vm@vsau.vin.ua).

ЗЕЛИНСКАЯ Оксана Владиславовна - кандидат технических наук, доцент, доцент кафедры компьютерных наук и економической кибернетики, Винницкий национальный аграрный університет (21008, г. Винница, ул. Солнечная, 3, e-mail: zeloksanavlad@gmail.com).

ПОТАПОВА Надежда Анатольевна - кандидат економических наук, доцент, доцент кафедри компьютерных наук и економической кибернетики, Винницький национальний аграрний університет $(21008, \quad$ г. Винниця, ул. Солнечная, 3, e-mail: potapova.nadin@gmail.com).

УДК 519.86:63:330.131.7

DOI: 10.37128/2411-4413-2020-1-8

ОСОБЛИВОСТІ

МОДЕЛЮВАННЯ В

СІЛЬСЬКОГОСПОДАР-

СЬКОМУ

ВИРОБНИЦТВІ 3

ВРАХУВАННЯМ

РИЗИКУ ${ }^{8}$
УШКАЛЕНКО І. М., кандидат економічних наук, доцент кафедри комп'ютерних наук та економічної кібернетики, ミ Вінницький національний аграрний університет (м. Вінниця)

Для сучасної економіки України аграрний сектор є вкрай важливою ланкою. Забезпечення економічної безпеки країни, зокрема ї̈ продовольчої складової, вирішення соиіальних проблем можливі тільки при створенні ефективного агропромислового виробництва, здатного функиіонувати в умовах ринкових відносин.

В умовах ринкової економіки значно ускладнилися процеси управління АПК, оскільки він розвивається в умовах невизначеності, що призводить до необхідності врахування не тільки традиційних чинників господарської діяльності, а й пропозиції та попиту на сільськогосподарську продукцію, погодних умов, які значною мірою зумовлюють економічну ్ㅗㅇ ефективність агропромислового комплексу. Основною складністю наукових досліджень: структурно-функиіональної організації АПК, щчо трансформується, його поведінки, аналізу, прогнозування розвитку, підготовки своєчасних управлінських рішень та оцінки їх можливих

8 УШКАЛЕНКО І.М., 2020 
наслідків є об'єктивно притаманна изьому комплексові невизначеність, яка породжується багатьма чинниками, найважливішими для сільськогосподарського виробництва є стан погоди та ринку, науково-технічний прогрес.

Необхідність урахування і керування погодним ризиком витікає з об'єктивних вимог ринкової економіки, що вимагає від підприємництва пошуку способів найкращої адаптації до зовнішніх і внутрішніх умов функціонування та розвитку виробництва. Сільськогосподарське виробництво постійно реформується, в ринкових умовах. Тому виникла необхідність розробки нових методологічних $і$ методичних підходів планування функиіонування та розвитку сільськогосподарських підприємств, об'єднань і АПК загалом. Дослідження ичих питань можливе на базі використання економіко-математичного моделювання та ЕОМ.

У статті розглянуто концепцію планування функціонування та розвитку підприємств АПК в умовах невизначеності, щзо трунтується на сукупності організаційно-економічних $i$ методичних підходів щодо формування прочесу планування, який створює для сільськогосподарських підприємств передумови найкращої адаптації виробництва в умовах погодного ризику, підвищує рівень конкурентоздатності підприємств.

Ключові слова: сільськогосподарське виробництво, планування, розвиток підприємств АПК, економіко-математичне моделювання, ризик, погодний ризик.

Літ. 12.

\title{
PECULIARITIES OF MODELING IN AGRICULTURAL PRODUCTION WITH RISK ACCOUNTING
}

\author{
USHKALENKO Irina, \\ PhD in Economics, \\ Associate Professor, Department of Economic Cybernetics, \\ Vinnytsia National Agrarian University \\ (Vinnytsia)
}

The causes of the risk inherent in any field of human activity, in particular for agricultural production are considered. AIC, in contrast to other branches of production, has a very important specific reason for the appearance of risk - weather conditions. Weather conditions are one of the main factors of the degree of uncertainty for agricultural production. When developing the organization of production of the agricultural sector, the natural and climatic conditions must be taken into account.

In the agroindustrial complex, weather risk is most important and the main task of modeling and optimizing agricultural production is the development of ways of taking into account and reducing the weather risk. Economic result, which is an indicator effectiveness production in agriculture economy, depends independent characteristics of weather conditions.

The problem of weather economic sustainability and risk far exceeds the problem of productive stability, because not only all agricultural industries, but also the national economy of the country as a whole are closely related to agricultural production. The instability of agricultural production significantly affects all the integral indicators of the national economy, including the volume of the national product.

In the agroindustrial complex, weather risk is most important and the main task of modeling and optimizing agricultural production is the development of ways of taking into account and reducing the weather risk. Economic result, which is an indicator effectiveness production in agriculture economy, depends independent characteristics of weather conditions, that is why it is a random variable. This applies to all regions, all forms of ownership, all types of agricultural activities. 
Weather conditions can not be managed, but they can be adapted to achieve maximum integral result. To do this, you must select the other projects, strategic and tactical solutions with multiple permissible ones. In principle, there is the ability to manage the characteristics of weather resistance economic efficiency. In this case, we must try to obtain the maximum economic effect not only in a separate weather situation, but also during the long term, so that the effectiveness of the production is as possible as possible in relation to the accidental weather conditions in the given climate zone.

Keywords: agricultural production, planning, development of agricultural enterprises, economic and mathematical modeling, risk, weather risk.

Lit.: 12.

\title{
ОСОБЕННОСТИ МОДЕЛИРОВАНИЯ В СЕЛЬСКОХОЗЯЙСТВЕННОМ ПРОИЗВОДСТВЕ С УЧЕТОМ РИСКА
}

\author{
УШКАЛЕНКО И.Н., \\ кандидат экономических наук, доцент \\ кафедры компьютерных наук и экономической кибернетики, \\ Винницкий национальный аграрный университет \\ (2. Винница)
}

Для современной эконолики Украины аграрный сектор является крайне важным звеном. Обеспечение экономической безопасности страны, в частности ее продовольственной составляющей, решения соичальных проблем возможны только при создании эффективного агропромышленного производства, способного функционировать в условиях рыночных отношений.

В условиях рыночной экономики значительно усложнились прочеессы управления АПК, поскольку он развивается в условиях неопределенности, что приводит к необходимости учета не только традиционных факторов хозяйственной деятельности, но и предложения и спроса на сельскохозяйственную продукцию, погодных условий, которые в значительной мере обусловливают экономическую эффективность агропромылленного комплекса. Основной сложностью научных исследований структурно-функциональной организации АПК, трансформируется, его поведения, анализа, прогнозирования развития, подготовки своевременных управленческих решений и оценки их возможных последствий объективно присущая этому комплексу неопределенность, которая порождается многими факторами, важнейшими для сельскохозяйственного производства является состояние погоды и рынка, научно-технический прогресс.

Необходимость учета и управления погодным риском вытекает из объективных требований рыночной экономики, требует от предпринимательства поиска способов лучшей адаптации к внешним и внутренним условиям функиионирования и развития производства. Сельскохозяйственное производство постоянно реформируется, в рыночных условиях. Поэтому возникла необходимость разработки новых методологических и методических подходов планирования функиионирования и развития сельскохозяйственных предприятий, объединений и АПК в целом. Исследование данных вопросов возможно на базе использования экономико-математического моделирования и ЭВМ.

В статье рассмотрена кониепция планирования функционирования и развития іे предприятий АПК в условиях неопределенности, основанный на совокупности организационно-экономических и методических подходов по формированию прочесса планирования, создает для сельскохозяйственных предприятий предпосылки лучшей 
адаптации производства в условиях погодного риска, повышает уровень конкурентоспособности предприятий

Ключевые слова: сельскохозяйственное производство, планирование, развитие предприятий АПК, экономико-математическое моделирование, риск, погодный риск.

Лит. 12

Постановка проблеми. Агропромисловий комплекс переживає значні соціально-економічні й організаційні зміни, на сільськогосподарських підприємствах відбувається об'єктивний процес трансформації їхньої виробничої структури. Сьогодні для України гостро стоїть завдання розроблення механізмів державної аграрної політики щодо підвищення ефективності використання наявного потенціалу аграрного сектору економіки. 3 цією метою особлива увага має бути сконцентрована на створенні передумов для його інституційного забезпечення, яке, передусім, передбачає розвиток сільських територій, формування механізмів взаємодії держави та аграрного бізнесу, ‡ розвиток системи сільськогосподарського дорадництва у вигляді інформаційної та консультаційної допомоги сільськогосподарським товаровиробникам i сільському населенню, розвиток дрібнотоварного сільгоспвиробництва, сільськогосподарської кооперації для забезпечення інтеграції особистих господарств населення у ринкові механізми функціонування аграрного сектору економіки [1].

Головне завдання структурної перебудови агропромислового комплексу i реформування агропромислового сектору економіки полягає у створенні сприятливого економічного середовища для його прискореного розвитку. Тому виникає необхідність розробки нових методологічних і методичних підходів планування функціонування та розвитку сільськогосподарських підприємств, їхніх об'єднань і АПК загалом. Сучасне планування виробництва в аграрному секторі економіки України неможливе без застосування методів економікоматематичного моделювання. На підприємства агропромислового комплексу впливає велика кількість факторів зовнішнього середовища, в результаті чого формується область невизначеності умов, на базі яких приймаються управлінські рішення. Результативному функціонуванню та розвиткові економіки, як системи певного ієрархічного рівня сприятимуть інноваційні підходи до розв'язання відповідних задач стосовно вибору оптимальних управлінських рішень в умовах конкуренції, невизначеності та ризику, де зустрічаються інтереси різних сторін зі своїм баченням економічної ситуації (конфліктні ситуації). Для вирішення проблем традиційно залучаються відповідні економіко-математичні моделі [2]. Результатом використання моделювання стане можливість збалансування виробничої структури, пристосування іï до конкретних умов господарювання та підвищення ефективності планування діяльності.

Основною складністю наукових досліджень структурно-функціональної організації АПК, що дотепер трансформується, його поведінки, аналізу, прогнозування розвитку, підготовки своєчасних управлінських рішень та оцінки їхніх можливих наслідків $є$ об’єктивно притаманна цьому комплексові 
невизначеність, яка породжується багатьма чинниками. Вплив природних факторів зумовлює необхідність розробки в господарствах різних оптимальних варіантів моделей виробничої структури, виходячи зі ступеня сприятливості погодних умов.

Аналіз останніх досліджень та публікацій. Питання стратегікоінституційних засад ефективного використання потенціалу аграрного сектору економіки у контексті означення сучасного стану, розглядається у праці вітчизняного вченого Г.М. Калетніка, де проаналізовано результати та динаміку розвитку суб'єктів господарювання - виробників сільськогосподарської продукції [1]. Питанням застосування економіко-математичного інструментарію в діяльності сільськогосподарських підприємств вже давно приділяється увага в працях як зарубіжних, так i вітчизняних вчених. Практичне застосування моделювання, зокрема теорії ігор для аналізу ризиків процесів функціонування сільськогосподарських підприємств на основі моделей складових результативності розглянуто у працях Н.В. Бурєннікової - В.О. Ярмоленка [2]. Проблеми планування в умовах невизначеності досліджував видатний вчений- है. економіст М.Д. Кондратьєв [3]; питання планування та управління в умовах невизначеності неповної інформації розглядається в багатьох літературних джерелах. Автори І.Г. Соколов і В.О. Смірнов [4] у декількох роботах вивчають: питання надійності та гнучкості економічних систем. Управління в умовах: невизначеності розглядається в роботі М.Я. Петракова і B.I. Ротаря [5]. В основному це методи стохастичного програмування, які відкидають або недостатньо враховують механізм адаптації системи до умов середовища, що часто змінюються. Робиться акцент на суто ймовірностні, усереднені оцінки параметрів. Над проблемами стійкості розвитку сільськогосподарських підприємств працювали І.П. Бойко, В.А. Кардаш, І.Б.Загайтов, П.Д. Половинкін. та ін.

Мета статті. Дослідити методології та методики аналізу, моделювання і оптимізації функціонування та розвитку сільськогосподарських підприємств, 志 об'єднань і АПК загалом в умовах невизначеності (погодного ризику), та проаналізувати можливості подолання невизначеності, що породжує нестійкість функціонування та розвитку АПК, економічний ризик тощо. Тому методологія та методи планування цього комплексу повинні враховувати цей феномен.

Виклад основного матеріалу. Як показує досвід вчених-економістів, всебічний аналіз економічної системи вказує, що вона за умов стабільного розвитку є інерційною і при виникненні збурення постійно прагне повертатись у положення рівноваги. Одним 3 інструментів такого розвитку економічної системи $\epsilon$ детальна розробка прогнозних планів, спрямованих на краще пристосування економічної системи до змін умов зовнішнього середовища, స్ причому потенційні можливості повинні використовуватися найбільш ঝे раціонально. Використання та створення прогнозних планів як на мікро-, так і на макрорівні складних економічних систем дозволить виділити найбільш перспективні напрямки діяльності, вчасно зосередити в обраних напрямках 
потрібну кількість виробничих засобів з максимальним економічним ефектом.

При становленні країни на засади ринкового господарства одне з важливих місць у виробничій діяльності підприємства відводиться плануванню (прогнозуванню), як одному з головних чинників зниження економічного ризику діяльності підприємств. Докорінна зміна господарчого ладу певним чином відображається на методах планування. Якщо в умовах адміністративнокомандної економіки плани мала за основу директивні вказівки, то тепер кожному підприємству необхідно розробляти індивідуальний виробничий план і прогнозні розрахунки, які переважно носять імовірнісний характер.

У теперішній час, хоч і недостатньо, в науковій літературі розглядаються питання керування економічними системами в умовах невизначеності. Цікавість до цієї проблеми виникла порівняно недавно. Використання обчислювальної техніки та економіко-математичних методів створили передумови для практичного розв'язування задач керування в умовах невизначеності. Проте, варто відзначити, що розроблені економіко-математичні моделі, як правило, детерміновані, а, значить, не адекватно описують економічні процеси і тому отримані для них оптимальні рішення в якості планів виробничої діяльності рідко використовуються в практичній діяльності.

Залишається відкритим питання врахування головних функціональних характеристик планів (стійкість, ризик) та їх властивостей адаптації (надійність, гнучкість, еластичність, напруженість). Тому треба велику увагу приділяти вивченню функціональних характеристик та адаптивних властивостей планів та рішень, які приймаються [6].

Агропромисловий комплекс визначається як складна виробничоекономічна система взаємопов'язаних галузей та сфер господарства, що забезпечують виробництво продуктів харчування та інших товарів із сільськогосподарської сировини. Розв'язування задачі оптимізації - досягнення належного рівня ефективності полягає не лише в простій максимізації показників діяльності галузей сільського господарства. Кожна ланка АПК повинна відповідати певним кількісним та якісним вимогам, однією з яких є стійкість. При відсутності належного рівня стійкості сукупність змін елементів цілісної структури, акумулюючись, може приводити до перетворень, що порушують стійкість всієї системи. Виходячи із загальних закономірностей розвитку та функціонування складних систем потрібно відзначити, що АПК в процесі розвитку змінюючись під впливом зовнішніх та внутрішніх факторів постійно прагне досягти рівноваги, що забезпечується лише належним рівнем стійкості розвитку кожної з галузей як структурних елементів складної системи [7].

Причини виникнення ризику притаманні будь-якій галузі діяльності людини, зокрема, сільськогосподарському виробництву. АПК на відміну від інших галузей виробництва має дуже важливу специфічну причину появи ризику - погодні умови. Погодні умови є одним 3 головних чинників ступеня невизначеності для сільськогосподарського виробництва. При розробці організації виробництва підприємства аграрного сектору необхідно враховувати 
природно-кліматичні умови. Тобто при розміщенні та спеціалізації виробництва, розробці загальних систем землеробства використовується інформація про якість грунтів і кліматичні умови певного регіону, які вважаються умовно постійними, мало змінними. Крім кліматичних умов на процеси сільськогосподарського виробництва суттєво впливають погодні умови, які змінюються в значних межах. Тому методи організації та управління розвитку і функціонування процесів у АПК мають враховувати, що клімат і коливання погодних умов - дві різні за характером дії природного чинника.

Погодні умови змінюються з року в рік, впливаючи безпосередньо на основний показник діяльності АПК урожайність сільськогосподарських культур. Потрібно особливо відзначити, що коливання погодних умов недостатньо враховується в теоретичних розробках і практичній діяльності АПК.

Суттєвою особливістю погодного чинника $є$ випадковий характер його впливу, причому досить значного на результати діяльності АПК як в окремій зоні, так і в цілій країні. Врахування цього впливу в планово-економічній та управлінській діяльності АПК можливе лише при аналізі залежності витрат i результатів виробництва від випадкових характеристик погодних умов, а це вимагає суттєвої модифікації методології та методик планування та управління в цих областях діяльності, тобто використання понять економічного ризику та економічної стійкості виробництва.

Проблема погодної економічної стійкості та ризику значно ширша, ніж проблема продуктивної стійкості, тому що 3 сільськогосподарським 气̆ виробництвом тісно пов'язані не тільки всі галузі АПК, а також національне господарство країни загалом. Нестійкість сільськогосподарського виробництва суттєво впливає на всі інтегральні показники національного господарства, в тому числі і на обсяг національного продукту.

В агропромисловому комплексі найбільш важливим $\epsilon$ погодний ризик $\mathrm{i}$ основним завданням моделювання та оптимізації сільськогосподарського виробництва є розробка способів врахування та зменшення погодного ризику. Економічний результат, яким $є$ показник ефективності виробництва в сільському господарстві, залежить від випадкових характеристик погодних умов, тобто він $\epsilon$ випадковою величиною. Це стосується всіх регіонів, всіх форм власності, всіх видів агропромислової діяльності.

Погодними умовами неможливо керувати, але до них можливо адаптуватися з метою досягнення максимального інтегрального результату. Для цього потрібно вибрати ті чи інші проєкти, стратегічні та тактичні рішення із множини допустимих. При цьому потрібно намагатись отримати максимальний економічний ефект не тільки в окремій погодній ситуації, а і протягом довгого терміну, щоб цей ефект був би за можливості більш стійким до випадкових погодних умов у певній кліматичній зоні.

У зв'язку із суттєвим впливом погодних коливань на результати сільськогосподарського виробництва, одним із способів врахування погодного ризику є детальна розробка структури виробництва та варіантів управлінських 
рішень відносно кожної конкретної ситуації, які характеризуються певним набором погодних умов, що відображаються на урожайності технічних та кормових культур і пов'язаній з ними продуктивності худоби.

Одним 3 найбільш ефективних методів аналізу ризику є використання математичного моделювання. За допомогою математичних методів можливий детальний розгляд складних економічних процесів (явищ), розробка методів зменшення впливу ризику на виробничу діяльність, отримання найбільш ефективних управлінських рішень.

Будь-який процес виробництва визначається як діяльність складної, імовірнісної та динамічної соціально-економічної системи. Складність зумовлена існуванням різного типу зв'язків між елементами системи, а також набором зовнішніх чинників, що впливають на діяльність системи. Ймовірність виникає у зв'язку з властивостями випадковості та невизначеності в розвитку економічних процесів та явищ. Динаміка процесу виробництва відображається у зміні параметрів та структури соціально-економічних систем у часі.

Соціально-економічні системи належать до класу кібернетичних систем [8]. Застосування до опису економічних процесів та явищ саме кібернетичних систем зумовлене певною кількістю властивостей, притаманних саме такому виду систем. Кібернетичні системи є системами керованими, мають імовірний характер поведінки та здатність до взаємодії із зовнішнім середовищем; існують зворотні інформаційні канали, що дає змогу найбільш повного відображення економічних процесів.

Одним 3 головних методів дослідження систем $\epsilon$ математичне моделювання. Математичне моделювання - метод адекватного відображення найсуттєвіших властивостей об'єкта чи процесу шляхом створення їхніх математичних моделей i дослідження цих моделей. Економіко-математичні методи дозволяють отримати висновки не лише стосовно самої моделі, а також відносно визначеного оптимального розв'язку.

Сільськогосподарське виробництво, яке $\epsilon$ сегментом української економіки, в якому можна досить ефективно застосовувати методи економікоматематичного моделювання. Адже це виробництво характеризується обмеженістю в ресурсах, має певну систему показників ефективності та певну мету своєї діяльності і розглядаючи застосування економіко-математичного моделювання, необхідно брати до уваги специфіку функціонування сільського господарства, що буде зумовлювати і специфіку моделей.

Отже, дослідження процесів виробництва сільськогосподарської продукції, оптимізації іï структури, розподілу засобів виробництва та виробленої продукції, тобто планування сільського господарства, повинно враховувати всі можливі аспекти розвитку та функціонування АПК як складної системи.

Для аналізу процесів у сільському господарстві доцільно користуватись економічними показниками, які запропоновані в [9] і згрупувати їх таким чином:

1.Стосовно організаційної структури підприємств сільського господарства: 
- кількість підприємств аграрного сектору різних форм власності, співвідношення між ними, частка кожного з видів у виробництві товарної продукції та національному доході;

- собівартість продукції підприємств різних типів господарювання, рівень рентабельності, розподіл посівних площ та співвідношення рівнів продуктивності худоби;

- розміри сільськогосподарських підприємств, що містять вартість основних виробничих фондів, загальну земельну площу, чисельність худоби;

2. Показники аналізу функціонування окремих сільськогосподарських підприємств:

- рівень ефективності виробництва, критерієм якого $є$ прибуток, рентабельність;

- ефективність управління;

- наявність розширеного відтворення, соціальне та матеріальне становище робітників;

- рівень собівартості виробленої продукції, структура собівартості;

- реалізація виробленої продукції, виконання (не виконання) контрактів.

3. Показники (характеристики) функціонування та розвитку АПК загалом:

- рівень розвитку сільськогосподарського виробництва: нарощення об'ємів валової продукції, ріст рентабельності та прибутковості господарств;

- розвиток основних галузей - рослинництва та тваринництва;

- інтенсифікація сільськогосподарського виробництва - рівень урожайності культур та продуктивності худоби.

Неможливо побудувати одну складну модель, яка б змогла повністю й адекватно здійснити опис всього сільськогосподарського виробництва. Розв'язання проблеми стало можливим через розробку цілого комплексу моделей, сукупність яких найбільш точно враховує всі необхідні чинники і якомога точніше відображає певний економічний процес чи явище, що розглядається.

Для АПК розроблено достатню кількість базових моделей для опису процесів сільськогосподарського виробництва, спираючись на які можливо будувати необхідну для кожного конкретного випадку системи моделей. За сучасного стану побудови багатоукладної змішаної економіки важливою умовою створення адекватної моделі розвитку сільськогосподарського підприємства постає врахування динамічності та невизначеності зовнішньо економічного середовища і пов'язаного з ним економічного ризику.

Діяльність людини постійно обтяжена ризиком. Детерміновані ситуації, коли відсутній ризик, трапляються в людській діяльності досить рідко. Більшість невизначених подій, що спричиняють ризик $є$ неповністю прогнозованими та: контрольованими, їх неможливо усунути, а тому навіть на перший погляд досить ঝे ефективні рішення можуть призвести до значних збитків.

АПК значно більшою мірою обтяжений ризиком, ніж інші галузі. Щоб ефективно керувати аграрним сектором, необхідно враховувати важливі 
функціональні характеристики, в тому числі і ризик. У зв'язку з цим виникла необхідність детальної розробки математичних моделей для оптимізації в умовах невизначеності. Відповідно до характеру інформації про випадкові величини, що розглядаються в економічних задачах, можна виділити такі види моделей:

детерміновані моделі - всі величини відомі і постійні, або $\epsilon$ функціями відомих параметрів;

- стохастичні моделі - відомі розподіли ймовірностей випадкових величин;

- $\quad$ моделі в умовах невизначеності - невідомий розподіл хоча б однієї 3 випадкових величин.

В умовах ринкової економіки специфіка функціонування підприємств сільського господарства полягає в одночасній появі невизначеності на етапі прийняття рішення в умовах нестабільного ринкового середовища та суттєвого впливу некерованих чинників пов'язаних із самим процесом виробництва сільськогосподарської продукції. Тобто, мінливість погоди $є$ однією з основних причин невизначеності АПК.

Підсумовуючи вплив вище розглянутих чинників невизначеності, які вливають на процес функціонування і розвитку економічних систем, виділимо найбільш вагомі особливості виробництва сільського господарства:

- виробництво продукції рослинництва відбувається природнім шляхом i забезпечення необхідними умовами для розвитку рослин не може бути повністю контрольоване людиною;

- готова продукція тваринництва залежить від розвитку живих біологічних організмів і також $є$ джерелом невизначеності;

- підприємства сільського господарства у процесі виробництва використовують великі площі, звідси значне територіальне розрізнення господарчих підрозділів;

- усі процеси сільськогосподарського виробництва носять сезонний характер, що призводить до певної періодичності у виході готової продукції та витратах [9].

Основу побудови моделі для сільськогосподарського підприємства становлять показники, що стосуються безпосередньо процесу виробництва. Тому головним чинником раціонально розробленого прогнозу $\epsilon$ якомога детальніший математичний опис безпосередньо процесу виробництва. При моделюванні виробництва, важливою постає проблема врахування його умов, що залежить від впливу випадкових ринкових процесів. 3 цього погляду співвідношення галузей у сільськогосподарському підприємстві та його спеціалізація повинні задовольняти наявний попит на продукцію, одночасно найбільш повно використовуючи всі види ресурсів господарства. Такий підхід забезпечить мінімізацію фінансового ризику підприємства.

Результатом розрахунків за допомогою запропонованої моделі буде оптимальна структура виробництва для конкретного сільськогосподарського 
підприємства, що враховує наявні виробничі ресурси і умови, в яких функціонує господарство. Використання результатів оптимізації структури виробництва дає змогу найефективніше використати виробничий потенціал підприємства.

Стохастична, динамічна економіко-математична модель розвитку сільськогосподарського підприємства, що враховує вплив некерованих чинників на процес виробництва шляхом введення в модель змінних величин, що відповідає оптимальному рівню запасів для умов конкретного підприємства, дає можливість прийняття оптимальних управлінських рішень. Застосування розробленої за допомогою такої моделі структури виробництва дасть змогу досягти найвищої ефективності при зведеному на мінімальний рівень впливу економічного ризику на фінансові результати.

Суттєва роль у сільськогосподарському виробництві відводиться імовірнісним чинникам. Серед них головними $є$ випадкові погодні умови та розвиток біологічних організмів. Тому важливим доповненням для розробки ефективного фінансового плану є врахування імовірнісних факторів пов'язаних 3 погодними умовами, що дозволяє суттєво зменшити економічний ризик. Інструментом для розв'язання такої проблеми $є$ стохастичне програмування. Стохастична оптимізаційна модель відрізняється від детермінованої тим, що враховуються розподіли ймовірностей випадкових величин. Розв'язання такого типу задач, як правило, призводить до детермінованого випадку врахування : випадковості, а значить, i ризику за допомогою фіксованих властивостей випадкових величин: відомих значень дисперсій та ймовірностей.

Важливою перевагою стохастичних оптимізаційних моделей є здатність розробки рішення, що буде найкращим не лише в одній фіксованій ситуації, а відносно цілого набору можливих ситуацій. Найбільш складними до розгляду є оптимізаційні задачі в умовах невизначеності, розв'язання яких грунтується на теорії ігор. Для моделювання процесів сільського господарства оптимізаційні задачі такого плану розглядаються як гра відносно природи.

У випадку, коли за умов складності економіко-математичної моделі не можливо отримати аналітичний розв'язок, їх використовують для імітації, тобто будують так звані імітаційні моделі. Фактично імітаційна модель в цьому випадку передбачає розрахунковий комплекс, що дозволяє повністю проаналізувати процес 3 погляду можливих варіантів сполучення змінних величин відповідних наборів можливих результатів.

Імітація можливих варіантів розвитку виробництва, що зумовлені різними погодними умовами, на основі розробленої оптимізаційної моделі структури виробництва дозволяє завчасно визначити слабкі місця даного підприємства та розробити способи досягнення максимальної стійкості розвитку виробництва. ్ㅡ Імітаційне моделювання дозволяє також проводити багатогранні дослідження не : лише поведінки системи загалом, а також щодо ефективності прийняття тих чи ঝे інших управлінських рішень стосовно діяльності підприємства.

Найбільш складними є завдання оптимізації, які розв'язуються в умовах невизначеності. Чинники, що зумовлюють появу невизначеності можливо 
згрупувати за двома напрямками: соціально-економічні і техніко-економічні [11]. До соціально-економічних, наприклад, можна віднести проблему недостовірність інформації, яка використовується. Під техніко-економічними причинами недетермінованості розуміють невизначеність виробництва, пов'язаного 3 відхиленнями реального процесу від ідеального, добре розробленого. Наприклад, невизначеність може виникати у зв'язку 3 випереджувальним ростом вартості виробництва через збільшення термінів будівництва чи експлуатації об’єкта порівняно із запланованим. Усі вище згадані причини $є$ важливими передумовами для введення в моделі чинників, які враховують невизначеність. Найбільш адекватні і складні моделі досліджують дію кожного з цих чинників як окремо, так і у взаємодії один з одним. Однак, це дуже ускладнює саму модель.

Для виявлення головних принципових особливостей управління економічною системою в умовах невизначеності достатньо розглянути ситуацію, - коли випадковість виникає хоча б в одному моменті функціонування. Важливим дослідженням такого плану є розроблена в роботі М.Я. Петракова, B.I. Ротаря модель управління багатогалузевою економікою в умовах невизначеності [5]. Випадковими вважаються граничні потужності, тобто недетермінованість виходу продукції на одиницю проектної потужності. Така невизначеність - дуже часте явище в реальних економічних процесах і може розглядатись як суттєва характеристика системи загалом.

Головна ціль задачі описати залежність розподілу макрохарактеристик системи $K$ від розподілу величини $v$. Математично в задачі знаходиться розподіл мінімуму багатьох незалежних величин для випадкових величин 3 різними розподілами ймовірностей.

Для випадку, який враховує принцип невизначеності отримали таку модель:

$$
\begin{gathered}
V_{j}=\theta_{j} \xi_{j} ; \\
K=\theta(n) \xi_{0} ;
\end{gathered}
$$

де $K$ - максимальний кінцевий випуск в заданих пропорціях при обмеженнях на потужності виробництва; $V_{j}$ - приведені граничні потужності виробництва; $\theta_{j}$ - коефіцієнти масштабу при малих значеннях приведених потужностей виробництва, $\xi_{I}-$ випадкова величина.

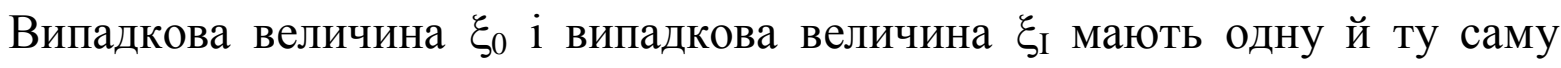
функцію розподілу - 1-exp $\{-\mathrm{x}\}, \theta(\mathrm{n})$ визначається за формулою:

$$
\frac{1}{\bar{\theta}(n)^{\alpha}}=\sum_{j=1}^{n} \frac{1}{\theta_{j}^{\alpha}}
$$

При реалізації цієї моделі багатогалузевої економіки отримали значення керованих параметрів. При великих $n$ розподіл макрохарактеристик $K$ залежить 
лише від параметрів $\alpha$ i $\theta$. При цьому керований параметр $\alpha$ характеризує стабільність системи. При $\alpha \rightarrow \infty,[\mathrm{K} / \theta$ (n) $] \rightarrow 1$.

Відносно поведінки характеристики $K$, виходячи з (2) отримали, що вона визначається лише макропараметром $\theta(\mathrm{n})$, і $\theta(\mathrm{n}) \rightarrow 0$ при $\mathrm{n} \rightarrow \infty$. Тобто, якщо число галузей велике, то хоча б в одній з них буде зрив.

Авторами (М.Я. Петраковим, В.І. Ротарем) запропоновано два виходи: стабілізація поведінки кожної з галузей і збільшення $\theta$ з ростом масштабу галузі. Вони вказали і на деякі недоліки моделі. Наприклад, одним із суттєвих недоліків є жорсткість критерію К, який не передбачає заміну продукту. Однак, загалом моделі дають можливість математично точно описати економічні задачі пов'язані з неповнотою інформації. Урахування принципу невизначеності в моделюванні процесів функціонування економіки надає особливого змісту питанням оптимізації. Оптимальний план виступає не лише завданням, що орієнтується на максимальний випуск продукції у відповідних пропорціях, а також план, який забезпечує заданий рівень стабільності, надійності досягнутої інтенсивності суспільного виробництва.

У тих випадках, коли аналітичні математичні моделі неефективні, доцільно використовувати імітаційні методи, для яких не є необхідні ні лінійність, ні постійність зв'язків, тобто структура імітаційних моделей не залежить відミ методів розв'язування цих моделей. Таке моделювання дозволяє користуватись не лише одним математичним методом. Імітаційні моделі дозволяють 3 досить великою точністю відобразити реальну дійсність. У сільському господарстві імітаційне моделювання може бути ефективно застосоване для оцінки економічності варіантів технології і організації виробництва в рослинництві, 辛 тваринництві або для оцінки динаміки структурних параметрів виробничоекономічного процесу, але у випадках, коли число таких параметрів не велике.

У роботі [12] імітаційне моделювання застосовується для прогнозу розвитку фермерських господарств під впливом цінової, податкової і кредитної політики держави. Модель передбачає імітацію функціонування декількох фермерських господарств, які мають однакову кількість основних фондів, матеріальних ресурсів, однакову технологію виробництва. Продукція реалізується на ринку загалом на однакових для всіх умовах. Модель враховує взаємодію фермерів з ринками основних фондів і матеріальних ресурсів. При цьому враховано випадкові коливання цін у певних межах і задається експертомз тенденція, динаміка їхніх змін.

Багато уваги приділено в моделі кредитно-фінансовим відношенням, адекватно моделюється система оподаткування. У моделі вводиться річний часовий крок. Моделювання починається 3 планового рішення про оптимальне використання ресурсів. Подальший розвиток моделюється наступним чином: отримана продукція (з урахуванням стохастики врожайності) реалізується у ڤે вигляді прибутку, з якого виплачуються податки, внески за кредит і таке інше. Виходячи із залишку грошей (якщо вони відсутні розглядається випадок банкрутства) фермерське господарство формує завдання прийняття рішення 
наступного року. Стратегічні і тактичні плани є результатом оптимізації лінійних моделей. Стратегічний план отримують у результаті реалізації на ЕОМ такої економіко-математичної моделі:

$$
\begin{gathered}
\sum_{i \in I} a_{i k} x_{i} \leq f_{k}-y_{k}+z_{k}, \\
y_{\mathrm{k}} \leq \lambda \mathrm{f}_{\mathrm{k}}, \\
\sum_{k \in K} d_{k} \sum_{i \in I} a_{i k}, x_{i} \leq D_{0}, \\
\mathrm{D}_{\mathrm{u}}+\mathrm{D}_{0} \leq \mathrm{D} \\
\sum_{i \in I} r_{i} x_{i} \rightarrow \max .
\end{gathered}
$$

Відповідно тактичний план одержимо за цією моделлю:

$$
\begin{gathered}
\sum_{i \in I} a_{i k} x_{i} \leq f_{k}, \\
\sum_{k \in K} d_{k} \sum_{i \in I} a_{i k}, x_{i} \leq D+K, \\
\mathrm{~K} \leq \mathrm{K}^{\prime} \\
\sum_{\mathrm{i} \in \mathrm{I}} \mathrm{p}_{\mathrm{i}} \mathrm{x}_{\mathrm{i}}-(1+\eta) \mathrm{K} \rightarrow \max ,
\end{gathered}
$$

де $\mathrm{a}_{\mathrm{ik}}$ - матриця прямих витрат (продукт $i$ по виду $k$ фондів); $\mathrm{C}_{\mathrm{k}}$ - ціна закупки устаткування виду k'; $\mathrm{C}_{\mathrm{k}}$ " - ціна продажу устаткування виду k"; $\mathrm{d}_{\mathrm{k}}-$ оборотні фонди; $\mathrm{D}_{\mathrm{u}}$ - кошти на закупку устаткування; $\mathrm{D}_{0}$ - засоби поповнення оборотних фондів; D - кошти фермера; K - кредит, що отримав фермер; K'кредитне обмеження; $\mathrm{f}_{\mathrm{k}}$ - наявні основні фонди; $\lambda$ - коефіцієнт ліквідності фондів; $\mathrm{p}_{\mathrm{i}}$ - прибуток продукції i-го виду; $\mathrm{r}_{\mathrm{i}}$ - рентабельність виробництва продукції виду $\mathrm{i} ; \mathrm{x}_{\mathrm{i}}$ - план виробництва продукції; $\mathrm{y}_{\mathrm{k}}$ - продані і $\mathrm{z}_{\mathrm{k}}$ - куплені фонди.

Ця модель 3 недостатньою точністю відображає реальні процеси, концентрується увага в основному на головних моментах. Доцільним є аналіз економічної проблеми як на основі розрахунків за моделлю, так і на основі висновків експерта. Така технологія належить до спеціального наукового напрямку - експериментальна економіка.

Висновки. Пріоритетним напрямком у розробці сучасних методів керування економічними системами в нестабільних ринкових умовах $\epsilon$ створення адаптивних організаційних структур, що швидко реагують на зміни у внутрішньому та зовнішньому середовищі. 3 цією метою необхідно використовувати нові економіко-математичні моделі, які достатньо точно описують складні, динамічні, стохастичні процеси сільськогосподарського виробництва. Таким чином, аналізуючи розглянуті моделі, можна зробити 
висновок, що вони не достатньо враховують основні чинники невизначеності, пов'язані як 3 природними аспектами виробництва сільськогосподарської продукції, так і з коливаннями кон'юнктури ринкового середовища.

\section{Список використаних джерел}

1.Калетнік Г.М. Стратегіко-інституційні засади ефективності використання потенціалу аграрного сектору економіки. Економіка, Фінанси, Менеджмент: актуальні питання науки і практики. 2015. № 1. С. 3-15.

2.Бурєннікова Н.В., Ярмоленко В.О., Юрченко О.М. Практика використання ігрових моделей для аналізу ризиків процесів функціонування сільськогосподарських підприємств на основі показників складових результативності. Бізнесінформ. 2018. № 6. С. 153-159.

3.Кондратьев Н.Д., Яковец Ю.В., Абалкин Л.И. Большие циклы конъюнктуры и теория предвидения. Избранные труды. Москва: Экономика, Зิ 2002. C. 550.

4.Соколов В.Г., Смирнов В.А. Исследование гибкости и надежности है экономических систем. Новосибирск: Наука. Сиб. отделение, 1990. 253 с.

5.Петраков Н. Я., Ротарь В. И. Фактор неопределенности и управление экономическими системами. Москва: Наука, 1995.

6.Савіна С.С. Адаптивне моделювання сільськогосподарським виробництвом за умов погодного ризику: автореф. дис. на здобуття наук. ступеня канд. техн. наук : спец. 08.03.02 - «Економіко-математичне моделювання». Київ, 1998, $20 \mathrm{c}$.

7.Наукове товариство Івана Кушніра. АПК України: загальна характеристика. URL: http:// nauka.kushnir.mk.ua (дата звернення: 10.03.2020).

8.Андрийчук В. Г., Наконечный С. И. Математическое моделирование экономических процессов сельскохозяйственного производства: Учебное пособие. Київ: КИНХ, 1982, 97 с.

9.Ковальчик М. І. Економічний аналіз у сільському господарстві : Навч.метод. посібник для самостійного вивчення дисц. Київ : КНЕУ, 2002, 282 с.

10.Щетинін А. І. Політична економія: підручник. Київ : ЦУЛ, 2011, 480 с.

11.Вітлінський В. В. Аналіз, оцінка і моделювання економічного ризику. Київ : «Деміург», 1996, 199 с.

12.Наконечний C.I., Савіна С.C. Оптимізація структури галузей сільськогосподарського підприємства в умовах невизначеності. Збірник матеріалів периої Всеукраїнської економетричної конферениії «Економетричн методи і моделі в економіці. Теорія та практика», Ч. 3., Львів, 1998. С.74-83.

\section{References}

1.Kaletnik H.M. (2015) Stratehiko-instytutsijni zasady efektyvnosti vykorystannia potentsialu ahrarnoho sektoru ekonomiky. Ekonomika, Finansy, ؛ Menedzhment: aktual'ni pytannia nauky i praktyky. № 1. 3-15: 06.04.2020) [in Ukrainian].

2.Buriennikova N.V., Yarmolenko V.O., Yurchenko O.M. (2018) Praktyka 
vykorystannia ihrovykh modelej dlia analizu ryzykiv protsesiv funktsionuvannia sil's'kohospodars'kykh pidpryiemstv na osnovi pokaznykiv skladovykh rezul'tatyvnosti. Biznesinform. № 6. 153-159 [in Ukrainian].

3. Kondrat'ev N.D., Yakovets Yu.V., Abalkyn L.Y. (2002) Bol'shye tsykly kon'iunktury y teoryia predvydenyia. yzbrannye trudy. M.: Ekonomyka. 550 [in Ukrainian].

4. Sokolov V.H., Smyrnov V.A. (1990) Yssledovanye hybkosty y nadezhnosty ekonomycheskykh system. Novosybyrsk: Nauka. Syb. Otdelenye. 253 [in Ukrainian].

5. Petrakov N. Ya., Rotar' V. Y. (1995) Faktor neopredelennosty y upravlenye ekonomycheskymy systemamy. M.: Nauka. [in Ukrainian].

6. Savina S.S. (1998) Adaptyvne modeliuvannia sil's'kohospodars'kym vyrobnytstvom za umov pohodnoho ryzyku : avtoref. dys. na zdobuttia nauk. stupenia kand. tekhn. nauk : spets. 08.03.02 - «Ekonomiko-matematychne modeliuvannia». Kyiv. 20 [in Ukrainian].

7. Naukove tovarystvo Ivana Kushnira. APK Ukrainy: zahal'na kharakterystyka. URL : http:// nauka.kushnir.mk.ua (data zvernennia: 10.03.2020) [in Ukrainian].

8. Andryjchuk V.H., Nakonechnyj S.Y. (1982) Matematycheskoe modelyrovanye ekonomycheskykh protsessov sel'skokhoziajstvennoho proyzvodstva: Uchebnoe posobye. K.: KYNKh. 97 [in Ukrainian].

9. Koval'chyk M.I. (2002) Ekonomichnyj analiz u sil's'komu hospodarstvi : Navch.-metod. posibnyk dlia samostijnoho vyvchennia dysts. K. : KNEU. 282 (data zvernennia: 10.03.2020) [in Ukrainian]. Ukrainian].

10. Schetynin A.I. (2011) Politychna ekonomiia: pidruchnyk. K. : TsUL. 480 [in

11. Vitlins'kyj V.V. (1996) Analiz, otsinka i modeliuvannia ekonomichnoho ryzyku. K. : «Demiurh». 199 [in Ukrainian].

12. Nakonechnyj S.I., Savina S.S. (1998) Optymizatsiia struktury haluzej sil's'kohospodars'koho pidpryiemstva v umovakh nevyznachenosti. Zbirnyk materialiv pershoi Vseukrains'koi ekonometrychnoi konferentsii "Ekonometrychni metody $i$ modeli v ekonomitsi. Teoriia ta praktyka», Ch. 3., L'viv. 74-83. [in Ukrainian].

\section{Відомості про автора}

УШКАЛЕНКО Ірина Миколаївна - кандидат економічних наук, доцент кафедри комп'ютерних наук та економічної кібернетики Вінницького національного аграрного університету (вул. Сонячна 3, м. Вінниця, 21008, e-mail: irinavnau@gmail.com).

USHKALENKO Irina - PhD in Economics, Associate Professor, Department of Economic Cybernetics, Vinnytsia National Agrarian University (21008, Vinnytsia, Soniachna str, 3, e-mail: irinavnau @gmail.com).

УШКАЛЕНКО Ирина Николаевна - кандидат экономических наук, доцент кафедры компьютерных наук и экономической кибернетики, Винницкого национального аграрного университета (ул. Солнечная, 3, г. Винница, 21008, еmail: irinavnau@gmail.com). 